\title{
Macroplastics on Soil-Plant System: Inhibiting Effects of Macroplastics on the Growth of Green Amaranth (Amaranthus viridis)
}

\author{
Marzan Ferdous, Arifur Rahman Bhuiyan*, Khadiza Akter Tania \\ Department of Environmental Science, Faculty of Science and Technology, Bangladesh University of Professionals, \\ Mirpur Cantonment, Dhaka, Bangladesh \\ Email: *arifur.rahman@bup.edu.bd
}

How to cite this paper: Ferdous, M., Bhuiyan, A.R. and Tania, K.A. (2021) Macroplastics on Soil-Plant System: Inhibiting Effects of Macroplastics on the Growth of Green Amaranth (Amaranthus viridis). American Journal of Plant Sciences, 12, 926-933.

https://doi.org/10.4236/ajps.2021.126062

Received: May 10, 2021

Accepted: June 20, 2021

Published: June 23, 2021

Copyright $\odot 2021$ by author(s) and Scientific Research Publishing Inc. This work is licensed under the Creative Commons Attribution International License (CC BY 4.0).

http://creativecommons.org/licenses/by/4.0/

(c) (i) Open Access

\begin{abstract}
In recent time Bangladesh faces a serious problem of soil pollution due to plastic contamination. However, the degree of the extent to which the effects of plastics on plant growth occur is not properly identified. An experiment was conducted to measure the effects of mixed plastic (polyethylene and disposable plastic glass) on the growth of Amaranthus viridis. Different doses of mixed plastics (T0, T1, T2, and T3) were applied with a fixed amount of soil for each of the treatments e.g., T0 (control), T1 (10 gm mixed plastics $/ 3 \mathrm{~kg}$ soil), T2 (15 gm mixed plastics $/ 3 \mathrm{~kg}$ soil) and T3 (20 gm mixed plastic/3kg soil), and the growth response of Amaranthus viridis against plastic was observed for six consecutive weeks. The growth was measured in terms of plant height and girth diameter. The results showed that the presence of mixed plastic had a significant effect on the growth of Amaranthus viridis and particularly in treatment T3 ( $3 \mathrm{~kg}$ soil $/ 20 \mathrm{gm}$ mixed plastic), the plants showed a slower growth response compared to control and the rest of the treatments applied in case of both plant height as well as girth diameter. The statistical analysis (one-way Analysis of Variance) also proved the significance of the treatments ( $\mathrm{p}$-values $<0.05)$ for six consecutive weeks. The experiment was successfully able to set an index on which plastics had their effects on the growth of green amaranth. In addition, the obtained data will be helpful in future research of the study in determining the possible effects of plastic on plant growth viz. green amaranth.
\end{abstract}

\section{Keywords}

Green Amaranth, Soil Pollution, Polyethylene Contamination, Disposable Plastic, Abiotic Stress, Slow Growth of Plants 


\section{Introduction}

Plastic is a synthetic polymer and without it, modern life would be impossible. Due to a wide spectrum of positive characteristics such as light, flexibility, nonrusting, and highly persistent, plastic products hold a very important role in our daily activities [1]. A tiny part of plastic used all over the world is being recycled or incinerated in waste-to-energy facilities. Bangladesh is reportedly 10th in plastic waste disposal in the world [2]. Every year 800,000 tons of waste are generated in Bangladesh, out of which 200,000 tons are from plastics [3]. However, the chemical bond of the monomers responsible for the durability of plastic makes it resistant to the different natural processes of degradation. The plastic waste does not decompose, rather they accumulate on landfill and marine environment [4]. Once in the soil, plastics can be further degraded into small particles via physical, chemical, and biological processes [5].

Additionally, the presence of plastic affects soil fertility in several ways. Plastics might alter the physico-chemical properties of soil by changing its texture and structure due to the distinctive characteristics of plastics compared with natural soil components [6]. When soil is contaminated with plastics, its pore structure, bulk density, and water holding capacity can be altered [7]; as a result, soil water evaporation and shrinkage cracking may also be affected. The composition and diversity of microbial communities in soils play an important role in maintaining soil quality [8] [9]. Microbes are sensitive to soil contaminants, and their composition and activity are the primary biological indicators of changes in the soil environment, as they play a key role in carbon, nitrogen, phosphorus, and potassium cycling in the soil [10] [11].

Soil enzymes with a high capacity for catalysis are closely associated with multiple soil biochemical processes; these enzymes act as an indicator for evaluating soil fertility and play an essential role in the regulation of soil nutrient cycling for nutrients such as $\mathrm{C}, \mathrm{N}$, and $\mathrm{P}$ [12] [13]. The soil system is the chief source for agriculture [14]. So maintained good soil conditions is mandatory to meet our present and future food demand. Some research already proves that Plastic waste remaining in a wide area of the soil are accumulating over a long period, causing the soil to harden and affects the crop's absorption of nutrients and water consequently. It leads to a reduction in crop outputs [15]. One Research also estimated the negative impacts of plastic bags on agriculture, e.g., reduction in soil fertility, decrease in nitrogen fixation, huge loss of nutrients in the soil, decrease in crop harvest, the disparity in flora, and fauna on soil, etc [16].

The present study examined the effects of mixed plastic on the growth of Green amaranth plants. The result of the study might help the researchers in a future study to identify the effects of plastic on plant growth and determine the threshold limit of plastics in soil against which plants can be able to grow.

\section{Materials and Methods}

\subsection{Experimental Procedure}

The experiment was carried out from August to December 2020. A Completely 
Randomized Design (CRD) was followed. The experimental procedure involved three steps:

2.1.1) Plant Preparation;

2.2.2) Soil Preparation;

2.2.3) Set up of the Experimental Pots.

\subsubsection{Plant Preparation}

Green amaranth was selected for this study which is a cosmopolitan species in the botanical family Amaranthaceae [17]. The reason for choosing green amaranth was, it is fast growing and the responses could be observed within the shortest period. It is an annual herb with an upright, light green stem that grows to about $60-80 \mathrm{~cm}$ in height. It has several nutritional values such as it can contain up to $38 \%$ protein by dry weight. The leaves and seeds contain lysine, an essential amino acid [18]. Seeds of green amaranth were collected from the seed market at Tongi, Gazipur, Dhaka, Bangladesh in July 2020. Seed viability test was carried out before planting by floatation method. The seeds were sown at first in the seedbed and allowed to grow until they were about $3.40-3.45 \mathrm{~cm}$ tall before transferring them into the treatment pots.

\subsubsection{Soil Preparation}

The experimental soil was silty loam, which was collected from a local nursery at Tongi, Dhaka, Bangladesh. After the soil was air dried, it was grounded with mortar and pestle and passed through a sieve and the $\mathrm{pH}$ was measured by using a $\mathrm{pH}$ meter.

Two types of plastic were used in this experiment: 1) polyethylene bag and 2) disposable plastic glass. For the experiment, both types of plastics were cut into pieces using scissors to reduce the plastic size. 10 grams, 15 grams, 20 grams of mixed plastics granule was prepared for three treatments and the ratio of onetime plastic glass and polyethylene was 1:2.3.

\subsubsection{Setup of Experimental Pots}

The experiment consisted of four (4) treatments each with three replications as follows:

$\mathrm{T} 0=$ control (untreated $3 \mathrm{~kg}$ soil);

$\mathrm{T} 1=0.33 \%$ treatment level ( $10 \mathrm{gm}$ shredded mixed plastic $/ 3 \mathrm{~kg}$ soil);

$\mathrm{T} 2=0.5 \%$ treatment level ( $15 \mathrm{gm}$ of shredded mixed plastic $/ 3 \mathrm{~kg}$ soil $)$;

$\mathrm{T} 3=0.66 \%$ treatment level $(20 \mathrm{gm}$ of shredded mixed plastic $/ 3 \mathrm{~kg}$ soil $)$.

Healthy and stable seedlings with a height of approximately $3.40-3.45 \mathrm{~cm}$ were uprooted from the seedbed and four seedlings were transplanted in each treatment pot. All the pots were exposed to natural sunlight conditions and care was taken to keep the plants free from weed or insect infestation. The plant height was observed for six consecutive weeks and was measured from the soil surface to the apical tip just after plantation. Plant steam diameters were measured in the $2^{\text {nd }}$ week, $4^{\text {th }}$ week, and $6^{\text {th }}$ week of the plantation. 


\subsection{Data Analysis}

All data were statistically analyzed by using Microsoft Excel (version 2010). One-way ANOVA (Analysis of Variance) was conducted to establish significant differences among the treatments at a 5\% level of significance using Microsoft Excel (version 2010).

\section{Results}

\subsection{Observation on Plant Height}

Measured average heights of Amaranthus viridis against different treatments were plotted against the number of observations (in weeks) and shown (Figure 1).

At 0 -week height of all treatment plants were approximately the same size $(3.42-3.45 \mathrm{~cm})$. At 1st week after planting, the plant's growth response of all the treatments was observed where all the treatments showed similar height except T3 $(5.36 \mathrm{~cm})$. This difference in treatment T3 has been distinctly observed after the $2^{\text {nd }}$ week, followed by the $3^{\text {rd }}$ week, and continued up to the $6^{\text {th }}$ week. On six weeks of observation, plants showed the slowest growth response in treatment T3. On the other hand, treatment T0 continued to show a significant response with the increase of plant height. Treatment T1, T2, and T3 showed a gradual decrease in the growth of plants (Figure 1).

After $3^{\text {rd }}$ week, a noticeable reduction of growth was observed in treatment T2 and T3 (Figure 1). In $4^{\text {th }}$ week, the value of treatment T0 was $20.98 \mathrm{~cm}$. However, the growth of plants in case of other treatments were $17.15 \mathrm{~cm}$ (T1), $15.15 \mathrm{~cm}$ (T2), $12.4 \mathrm{~cm}$ (T3) (Figure 1).

After the $5^{\text {th }}$ and $6^{\text {th }}$ week, the highest growth response was observed in T0 and the lowest was found in treatment T3. However, moderate growth was observed in treatment T1 and T2 (Figure 1). At $5^{\text {th }}$ Week the height of treatment T0, T1, and T2 was respectively $34.48 \mathrm{~cm}, 28.5 \mathrm{~cm}, 20.51 \mathrm{~cm}, 17.74 \mathrm{~cm}$ and for $6^{\text {th }}$ week $40.05 \mathrm{~cm}$ (T0), $35.52 \mathrm{~cm}$ (T1), $24.84 \mathrm{~cm}$ (T2), $19.6 \mathrm{~cm}$ (T3). So, it was clearly observed that $\mathrm{T} 3 \mathrm{had}$ the slowest growth response compared to the control $\mathrm{T} 0$, whereas treatment $\mathrm{T} 1$ and $\mathrm{T} 2$ had moderate growth response.

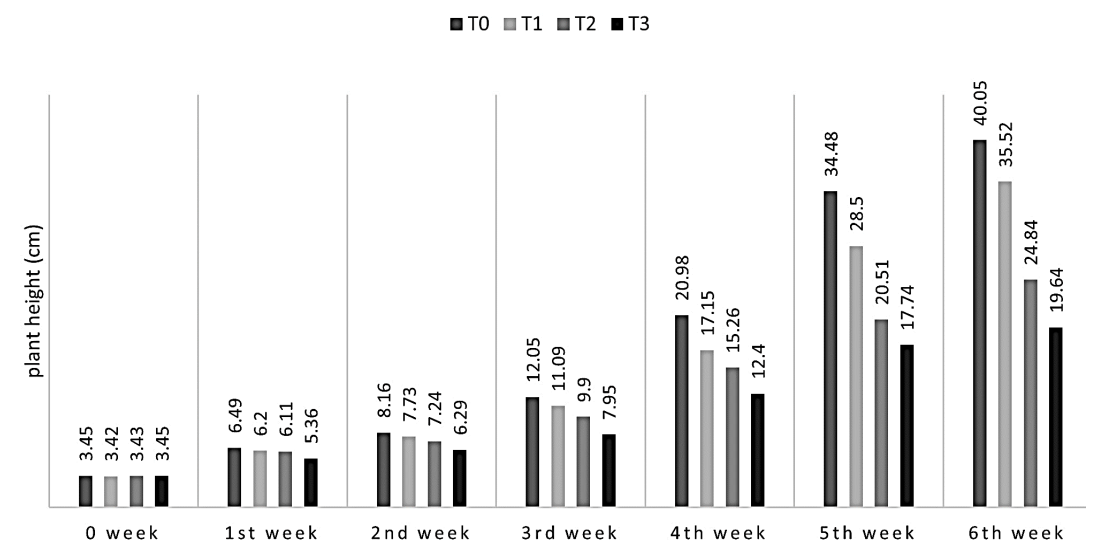

Figure 1. Average height $(\mathrm{cm})$ of Amaranthus viridis in six consecutive weeks. 
The similar result was found from some other researchers' experiment [19] [20]. They [19] conducted a study with five treatments in eight weeks. Among them, one treatment served as a control and the other contained several doses of polyethylene. They also identified significant height reduction of maize plants in the presence of polyethylene granules and observed the lowest growth rate in the highest doses of treatment. Another researcher also revealed that the presence of both macro-and micro-plastic residues of polyethylene mulch films has negative effects on both above-ground and below-ground parts of wheat [20].

\subsection{Observation on Steam Girth Diameter}

Figure 2 clearly indicates that, plants of treatment T0 had the widest diameter value $(0.9 \mathrm{~cm})$ while treatment T3 had the least stem girth diameter value $(0.56$ $\mathrm{cm}$ ) detected at the $6^{\text {th }}$ week of observation after the plantation. They [19] also found a similar result in their experiment 8 weeks after planting. They detected the reduction of girth diameter of Zea mays while several doses of polyethylene were applied.

\section{Discussion}

The results obtained from Sections 3.1 and 3.2, show that the growth (considering both height and girth diameter) of Amaranthus viridis was highest in the absence of mixed plastic in soil (T0). Whereas the presence of mixed plastics in treatment T1, T2, and T3 showed a reduction of growth rate in Amaranthus viridis (Figure 1 and Figure 2). Additionally, it had been observed that the higher the doses of plastics in treatment, the slower the growth rate e.g., the amount of mixed plastic was highest in treatment $\mathrm{T} 3$, and it showed the lowest growth rates of Amaranthus viridis. Hence the significant effect of mixed plastic on growth was clearly visualized with a gradual increase with time. For example, after 3rd week the growth reduction was more easily detected (Figure 1 and Figure 2). On the $4^{\text {th }}, 5^{\text {th }}$, and $6^{\text {th }}$ week, treatment $\mathrm{T} 2$ and T3 showed significantly slower growth response compared to other weeks (Figure 1). Girth diameter also reduced with time in the case of various treatments particularly in T3 (Figure 2).

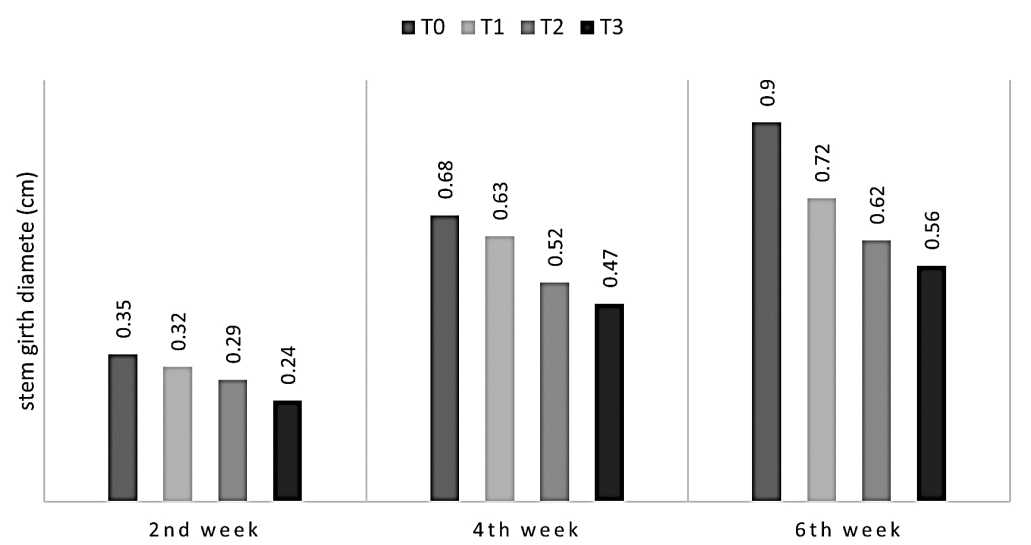

Figure 2. Average girth diameter of Amaranthus viridis observed at $2^{\text {nd }}, 4^{\text {th }}$, and $6^{\text {th }}$ week. 
The reasons behind this might be, with the increasing time plants need to uptake more nutrients for their growth. But the shredded plastic obstructs the free movement of root hair. Additionally, soil pore spaces also block by shredded plastics that contain adequate air and water. As a result, Amaranthus viridis root could not uptake sufficient water and nutrient for their growth. However, plant respiration was also hampered due to a lack of well-aerated conditions in the soil. As the presence of shredded mixed plastic disturbed soil natural condition, Amaranthus viridis growth was also affected.

\section{Statistical Analysis}

One-way ANOVA was done to determine the significance of the treatments applied at a 5\% level of confidence using Excel. ANOVA test also showed that, Amaranthus viridis height at the first week of observation, the p-value was 0.001185 which was less than 0.05 and it indicates that, there had been significant differences in the treatments. Additionally, the p-value of week 2, week 3 , week 4 , week 5 , and week 6 were respectively $1.8 \times 10^{-6}, 7.61 \times 10^{-11}, 1.95 \times 10^{-14}$, $4.07 \times 10^{-24}, 6.08 \times 10^{-26}$ and all the values were less than 0.05 for between and within the groups. It was also observed that after the $2^{\text {nd }}$ week the p-value was drastically reduced.

Similar results were also found in the case of steam girth diameter. The p-value of ANOVA test found for week 2, week 4, and week 6 was respectively $1.47 \times 10^{-9}, 1.35 \times 10^{-5}, 2.69 \times 10^{-10}$ and all the values were less than 0.05 for between and within groups which clearly indicate that there had been significant differences in the treatments applied to observe the plants growth. So, the statistics proved the significant differences between and within the groups (within treatments).

\section{Conclusion}

The study suggests that the presence of macroplastics in soil had significant effects on plant growth. The results also proved that there is a certain withstand point beyond which the plants will collapse to show any growth progress further. Thus, these indexing or threshold values could be helpful in future research and will provide valuable data regarding plant's tolerance limit against plastic contamination in soil.

\section{Conflicts of Interest}

The authors declare no conflicts of interest regarding the publication of this paper.

\section{References}

[1] Stubenrauch, S. and Ekardt, F. (2020) Plastic Pollution in Soils: Governance Approaches to Foster Soil Health and Closed Nutrient Cycles. Environments, 7, Article No. 38. https://doi.org/10.3390/environments7050038

[2] Chowdhury, G.W., Koldewey, H.J., Duncan, E., Napper, I.E., Niloy, H.N., Nelms, 
S.E., Sarker, S., Bhola, S. and Nishat, B. (2020) Plastic Pollution in Aquatic Systems in Bangladesh: A Review of Current Knowledge. Science of the Total Environment, 761, Article ID: 143285. https://doi.org/10.1016/j.scitotenv.2020.143285

[3] Begum, F.A. (2018) Sustainability of Plastic Sector. The Financial Express, Bangladesh.

[4] Browne, M.A., Crump, P., Niven, S.J., Teuten, E., Tonkin, A., Galloway, T. and Thompson, R. (2011) Accumulation of Microplastic on Shorelines Worldwide: Sources and Sinks. Environmental Science \& Technology, 21, 9175-9179.

https://doi.org/10.1021/es201811s

[5] Peng, J., Wang, J. and Cai, L. (2017) Current Understanding of Microplastics in the Environment: Occurrence, Fate, Risks, and What We Should Do. Integrated Environmental Assessment and Management, 13, 476-482. https://doi.org/10.1002/ieam.1912

[6] Wan, Y., Wu, C., Xue, Q. and Hui, X. (2019) Effects of Plastic Contamination on Water Evaporation and Desiccation Cracking in Soil. Science of the Total Environment, 654, 576-582. https://doi.org/10.1016/j.scitotenv.2018.11.123

[7] de Souza Machado, A.A., Lau, C.W., Till, J., Kloas, W., Lehmann, A. and Becker, R. (2018) Impacts of Microplastics on the Soil Biophysical Environment. Environmental Science \& Technology, 52, 9656-9665.

https://doi.org/10.1021/acs.est.8b02212

[8] Kennedy, A. C. and Smith, K. L. (1995) Soil Microbial Diversity and the Sustainability of Agricultural Soils. Plant \& Soil, 170, 75-86.

https://doi.org/10.1007/BF02183056

[9] Rong, Y., Wang, Y., Guan, Y., Ma, J., Cai, Z. and Yang, G. (2017) Pyrosequencing Reveals Soil Enzyme Activities and Bacterial Communities Impacted by Graphene and Its Oxides. Journal of Agricultural and Food Chemistry, 65, 9191-9199. https://doi.org/10.1021/acs.jafc.7b03646

[10] Avidano, L., Gamalero, E., Cossa, G.P. and Carraro, E. (2005) Characterization of Soil Health in an Italian Polluted Site by Using Microorganisms as Bioindicators. Applied Soil Ecology, 30, 21-33. https://doi.org/10.1016/j.apsoil.2005.01.003

[11] Bergkemper, F., Scholer, A., Engel, M., Lang, F., Kruger, Schloter, M. and Schulz, S. (2016) Phosphorus Depletion in Forest Soils Shapes Bacterial Communities Towards Phosphorus Recycling Systems. Environmental Microbiology, 18, 1988-2000. https://doi.org/10.1111/1462-2920.13188

[12] Allison, S.D. and Jastrow, J.D. (2006) Activities of Extracellular Enzymes in Physically Isolated Fractions of Restored Grassland Soils. Soil Biology and Biochemistry, 38, 3245-3256. https://doi.org/10.1016/j.soilbio.2006.04.011

[13] Trasar-Cepeda, C., Leiros, M.C. and Gil-Sotres, F. (2008) Hydrolytic Enzyme Activities in Agricultural and Forest Soils. Some Implications for Their Use as Indicators of Soil Quality. Soil Biology and Biochemistry, 40, 2146-2155. https://doi.org/10.1016/j.soilbio.2008.03.015

[14] Marie, M.J.A.M and Tiwari, D. (2020) Depleting the Usage of Plastics to Enhance the Agricultural Land. An Attitudinal Study for Sustainable Generation. Asian Journal of Education and Social Studies, 12, 1-6. https://doi.org/10.9734/ajess/2020/v12i230305

[15] Chae, Y. and An, Y.J. (2018) Current Research Trends on Plastic Pollution and Ecological Impacts on the Soil Ecosystem: A Review. Environmental Pollution, 240, 387-395. https://doi.org/10.1016/j.envpol.2018.05.008

[16] Jalil, A., Mian, N. and Rahman, M.K. (2013) Using Plastic Bags and Its Damaging 
Impact on Environment and Agriculture: An Alternative Proposal. International Journal of Learning and Development, 3, 1-14.

https://doi.org/10.5296/ijld.v3i4.4137

[17] Tanaka, Y. and Van, K.N. (2007) Edible Wild Plants of Vietnam: The Bountiful Garden. Orchid Press, Thailand.

[18] Grubb, A., Rowland, A.R. (2012) The Weed Forager's Handbook. Hyland House Publishing Pty Ltd., Australia.

[19] Atuanya, E.I., Aborisade, W.T. and Nwogu, N.A. (2012) Impact of Plastic Enriched Composting on Soil Structure, Fertility, and Growth of Maize Plants. European Journal of Applied Sciences, 4, 105-109.

[20] Qi, Y.L., Yang, X., Pelaez, A.M., Huerta, E., Beriot, N., Gertsen, H., Garbeva, P. and Geissen, V. (2018) Macro- and Micro-Plastics in Soil-Plant System: Effects of Plastic Mulch Film Residues on Wheat (Triticum aestivum) Growth. Science of the Total Environment, 645, 1048-1056. https://doi.org/10.1016/j.scitotenv.2018.07.229 